\title{
Electrochemical Impedance Biosensor for the Determination of Lipopolysaccharide Using Peptide as the Recognition Molecule
}

\author{
Xuemei Fan, ${ }^{\oplus a, b}$ Zhejian Li, ${ }^{\oplus a, b}$ Shumin Wang, ${ }^{*, a, b}$ Lei Liu, ${ }^{c}$ Ping Liu, ${ }^{a, b}$ \\ Fengying Chen ${ }^{a, b}$ and Xingwang Zheng ${ }^{c}$ \\ ${ }^{a}$ College of Chemical Engineering and Modern Materials, Shangluo University, \\ 726000 Shangluo, China \\ ${ }^{b}$ Key Laboratory of Tailings Resources Comprehensive Utilization in Shaanxi Province, \\ 726000 Shangluo, China \\ ${ }^{c}$ School of Chemistry and Chemical Engineering, Xi'an University of Science and Technology, \\ 710054 Xi'an, China
}

\begin{abstract}
A simple and sensitive electrochemical impedance spectroscopy (EIS) biosensor was designed for the determination of lipopolysaccharide (LPS). The gold nanoparticles (GNPs) were electrochemically deposited on the glassy carbon electrode as a base electrode and the biosensor was fabricated by self-assembling a special peptide (GIGKLHSAGKF) used as molecular recognition onto the GNPs surface according to the $\mathrm{Au}-\mathrm{S}$ bond. Polyethylene glycol and 6-mercapto-1-hexanol were used to block the remaining sites of the modified electrode surface. When binding of LPS, the biosensor had a good response to different concentrations of LPS and the charge transfer resistance of the biosensor was directly related to the logarithm of LPS concentrations in the range of $0.01 \mathrm{pg} \mathrm{mL}^{-1}-1.0 \mathrm{ng} \mathrm{mL}^{-1}$ with a limit of detection of $2.0 \mathrm{fg} \mathrm{mL}^{-1}$. The characteristics of the electrochemically deposited GNPs and the optimization concentration and the self-assembly time of peptide, as well as the performance of the EIS biosensors for LPS were investigated. The biosensor was used for real serum sample determination with satisfactory results.
\end{abstract}

Keywords: electrochemical impedance spectroscopy, peptide, lipopolysaccharide

\section{Introduction}

Lipopolysaccharides (LPS), known as "endotoxins", are the main lipid on the surface of Gram negative bacteria, which have the function of permeability barrier and make the outer membrane relatively impervious to hydrophobic antibiotics, detergents and host proteins. ${ }^{1}$ They are nontoxic when binding to the outer membrane of the bacteria, but toxic after released, and when immune cells are exposed to lipid A an inflammation is caused. ${ }^{2}$ Hence, it is necessary to establish an effective LPS assay for the study of cell function and disease diagnosis.

Up to now, many different analytical methods have been developed for the determination of LPS. The most commonly used technique is enzymatic limulus amebocyte lysate (LAL), which is similar to the ordinary digestion test, very sensitive, but the dependence on the $\mathrm{pH}$ and temperature environment is very high. ${ }^{3}$

*e-mail: happy6693@126.com
In recent years, colorimetric, fluorescent, electrochemical and electrochemiluminescence biosensors have been reported and applied for the detection of LPS, such as a colorometric LPS sensor based on the functionalized polydiacetylene liposomes providing the differential responses to specific LPS strains; ${ }^{4}$ a fluorescent probe for LPS by assembling tetramethylrhodamine-labeled LPS binding peptides on graphene oxide ${ }^{5}$ and a fluorescent sensor based on the interaction between LPS and quaternary ammonium; ${ }^{6}$ an electrochemical LPS sensor based on nicking endonuclease-assisted recycling for signal amplification ${ }^{7}$ and the double signal amplification of Ce-metal-organic frameworks (MOFs) and $\mathrm{Zn}^{2+}$ dependent deoxyribozyme (DNAzyme)-assisted recycling; ${ }^{8}$ a label-free "on-off" $\mathrm{MoS}_{2}$ quantum dots (QDs)-realized electrochemiluminescence aptasensor with aptamer recognition-driven target-cycling synchronized rolling circle amplification for the detection of LPS. ${ }^{9}$ Although some progress has been made on the determination of LPS, the method had the disadvantages of high cost, low 
selectivity and low sensitivity. Thus, it is necessary to develop a simple, sensitive and selective sensor for LPS.

Electrochemical impedance spectroscopy (EIS) is one of the most effective method to characterize the physicochemical processes of different modified layers, sampling charge transfer at high frequency and subsequent mass transfer at low frequency. ${ }^{10}$ EIS is one of the most convenient tools for monitoring the charge transfer processes of immunosensors, and it provides another way for biomolecular detection. ${ }^{11}$ Therefore, EIS has attracted wide attention in the field of LPS biosensor. Cho et al. ${ }^{12}$ reported an impedance sensor based on a $\mathrm{Cu}$ and nitrilotriacetic acid (NTA) complex and it provided detection of LPS. Su et al. ${ }^{13}$ developed an impedance biosensor using single-stranded (ss) deoxyribonucleic acid (DNA) aptamer as the biological recognition element. Brosel-Oliu et al. ${ }^{14}$ also reported an EIS biosensor for LPS based on a three dimensional electrode array modified with concanavalin A.

The synthesis of specific polypeptides is widely used in biological detection due to its advantages of reliability, economy, stability, resistance to harsh environment, and easier engineering design at the molecular level than antibodies, and is expected to replace traditional antibodies. ${ }^{15}$ Several bioassays using peptide as substrate have been developed, such as colorimetric, ${ }^{16-18}$ fluorescent, ${ }^{19-22}$ electrochemical ${ }^{23-26}$ and electrochemiluminescence. ${ }^{27-30}$ The aim of this paper was to design a simple and sensitive EIS biosensor for LPS by employing a specific peptide (GIGKLHSAGKF) ${ }^{31}$ as biological recognition molecule.

\section{Experimental}

\section{Reagents and apparatus}

A Zennium electrochemical workstation (Zahner, Germany) was used for the electrochemical measurements. A three-electrode system was composed of a glassy carbon electrode (GCE) or a fabricated biosensor as working electrode, a platinum plate as counter electrode, and $\mathrm{Ag} / \mathrm{AgCl}$ (saturated $\mathrm{KCl}$ ) as reference electrode. All potentials were referred to this reference electrode. Field emission scanning electron microscopy (SEM; Zeiss Sigma, Germany) was used to monitor the electrochemical deposition of the gold nanoparticles (GNPs).

Peptide (GIGKLHSAGKF) was purchased from Shanghai Sangon Biological Engineering Technology \& Service Co. Ltd. (China). Lipopolysaccharides from Escherichia coli O55:B5 were purchased from SigmaAldrich (USA) and were purified by the manufacturer. 6-mercapto-1-hexanol (MCH), polyethyleneglycol 1000 (PEG), bovine serum albumin (BSA), glucose (Glu) and cholesterol (Cho) were also purchased from SigmaAldrich (USA). Potassium ferricyanide, potassium ferrocyanide, sodium citrate, chloroauric acid were obtained from Xi' an Chemical Reagent Company (China). Peptide and LPS solutions were prepared by $0.1 \mathrm{~mol} \mathrm{~L}^{-1}$ phosphate buffer saline (PBS); $0.1 \mathrm{~mol} \mathrm{~L}^{-1} \mathrm{KH}_{2} \mathrm{PO}_{4} /$ $\left.\mathrm{Na}_{2} \mathrm{HPO}_{4}-0.1 \mathrm{~mol} \mathrm{~L}-1 \mathrm{KCl}, \mathrm{pH} 7.0\right)$. All other solutions were prepared with ultrapure water $(>18.2 \mathrm{M} \Omega \mathrm{cm})$ supplied by a Milli-Q Lab system.

\section{Fabrication of the biosensor}

A bare GCE was polished carefully to a mirror-like surface with 0.3 and $0.05 \mu \mathrm{m}$ alumina slurry, and then successively washed in an ultrasonic cleaner with ethanol and water. Before modification, the bare GCE was cyclic voltammetry scanned from -0.2 to $0.6 \mathrm{~V}$ in $0.01 \mathrm{~mol} \mathrm{~L}^{-1}$ $\mathrm{Fe}(\mathrm{CN})_{6}^{3-}$ solution containing $0.1 \mathrm{~mol} \mathrm{~L}^{-1} \mathrm{KCl}$ supporting electrolyte until a pair of rather well-defined redox peaks were obtained. As shown in Scheme 1, the designed biosensor was fabricated as followed: firstly, the polished GCE was immersed in $10 \mathrm{~mL}$ of $0.25 \mathrm{mmol} \mathrm{L}^{-1} \mathrm{HAuCl}_{4}$ and $7.5 \mathrm{mmol} \mathrm{L}^{-1}$ sodium citrate, while a constant potential of $+1.1 \mathrm{~V}$ ( $v s$. $\mathrm{Ag} / \mathrm{AgCl}$, sat. $\mathrm{KCl}$ ) was applied for $60 \mathrm{~s}$ and then a constant potential of $0 \mathrm{~V}$ was applied for $20 \mathrm{~s}$ under stirring. ${ }^{32}$ Then, $10 \mu \mathrm{L}$ of $1 \mathrm{mg} \mathrm{mL}^{-1} \mathrm{PEG}$ was drop-coated onto the freshly prepared GNPs/GCE for $30 \mathrm{~min}$ to block the remaining site. After that, $10 \mu \mathrm{L}$ of $4 \mu \mathrm{g} \mathrm{mL} \mathrm{m}^{-1}$ peptide was drop-coated onto PEG/GNPs/GCE for $100 \mathrm{~min}$. At last, the peptide self-assembled electrode was blocked with $10 \mu \mathrm{L}$ of $1.0 \mathrm{mmol} \mathrm{L}^{-1} \mathrm{MCH}$ for $30 \mathrm{~min}$ and the biosensor was obtained. Before any reagent immobilization step, each electrode was washed with $0.1 \mathrm{~mol} \mathrm{~L}^{-1} \mathrm{PBS}$. When not in use, the resulting electrode was stored in $0.1 \mathrm{~mol} \mathrm{~L}^{-1} \mathrm{PBS}$ ( $\mathrm{pH} 7.0)$ at $4{ }^{\circ} \mathrm{C}$.

\section{Electrochemical measurements}

The fabricated biosensor was immersed into $50 \mu \mathrm{L}$ of LPS with different concentration or sample for $50 \mathrm{~min}$, followed by a thorough washing with $0.1 \mathrm{~mol} \mathrm{~L}^{-1} \mathrm{PBS}$ ( $\mathrm{pH}$ 7.0) to remove the non-reacted LPS. Then, the fabricated biosensor was placed into an electrochemical cell with $10 \mathrm{~mL}$ of $5 \mathrm{mmol} \mathrm{L}{ }^{-1}\left[\mathrm{Fe}(\mathrm{CN})_{6}\right]^{3-14-}\left(0.10 \mathrm{~mol} \mathrm{~L}^{-1}\right.$ PBS, pH 7.0). The EIS measurement was taken and the amplitude of the applied sine potential in each case was $5.0 \mathrm{mV}$, whereas the bias potential of $+0.226 \mathrm{~V}$ was limited to the formal potential of the redox couple $\left[\mathrm{Fe}(\mathrm{CN})_{6}\right]^{3-/ 4-} .^{33}$ The electron transfer resistance were recorded and the 


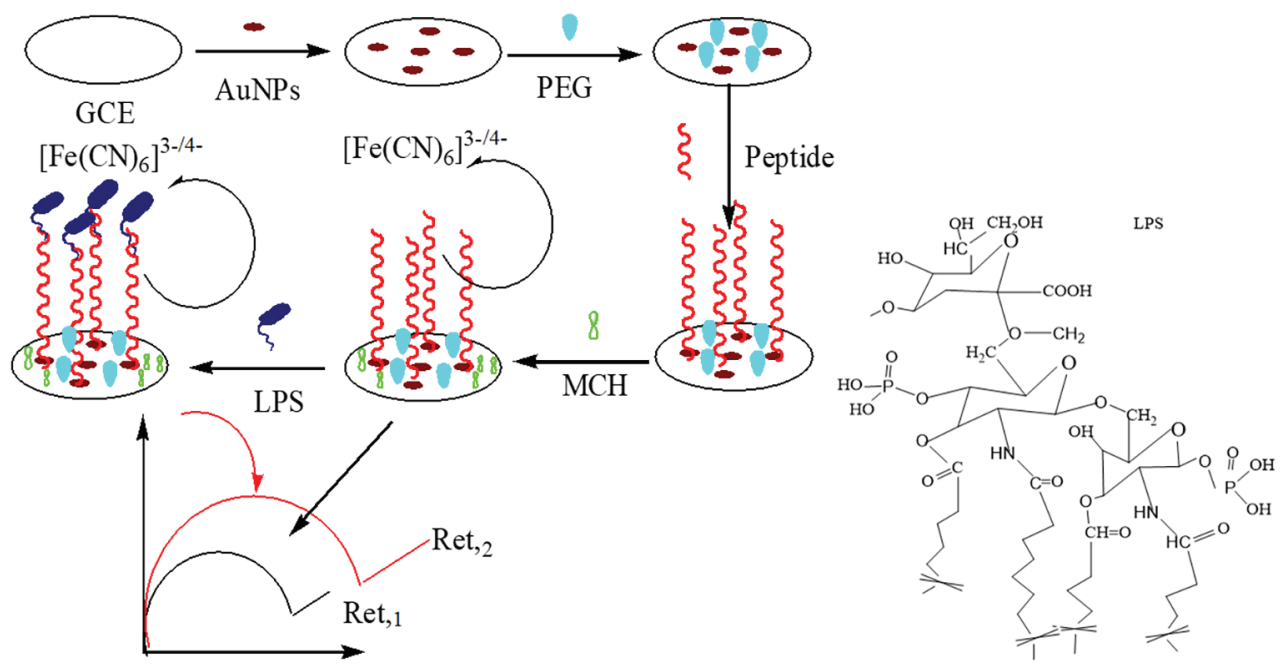

Scheme 1. Schematic illustration of the label-free EIS biosensor for LPS detection.

concentration of LPS was quantified by the increase of the electron transfer resistance $\Delta \mathrm{R}_{\mathrm{et}}\left(\Delta \mathrm{R}_{\mathrm{et}}=\mathrm{R}_{\mathrm{et}, \mathrm{i}}-\mathrm{R}_{\mathrm{et}, 0}\right)$, where $\mathrm{R}_{\mathrm{et}, 0}$ is the electron transfer resistance in the absence of LPS and $\mathrm{R}_{\mathrm{et}, \mathrm{i}}$ is the electron transfer resistance in the presence of LPS. All experiments were done under the same conditions of room temperature $\left(25 \pm 1^{\circ} \mathrm{C}\right)$.

\section{Results and Discussion}

\section{Characterization of GNPs}

The electrochemical deposition of GNPs was the most important step in the biosensor preparation because the size and density of the GNPs will affect the performance of the biosensor. The GNPs was obtained according to the literature. ${ }^{34}$ SEM was used to get the characterization of GNPs on the surface of GCE. The SEM images in Figure 1 showed that the surface of the bare GCE was rather smooth (Figure 1a), and the GNPs can easily be seen after the electrochemical deposition (Figure 1b). The mean size of GNPs in diameter was about $40 \mathrm{~nm}$.

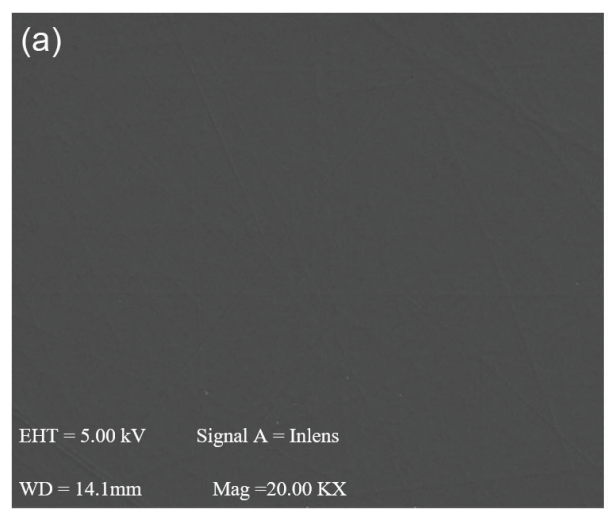

\section{Characterization of biosensor}

To prove the feasibility of this biosensing strategy, the EIS was used to study the interface properties of different modified electrode. Figure 2 depicted the Nyquist plots of different modified electrodes. The EIS data were fitted to a Randles equivalent circuit (Figure 2 inset), which included the resistance of the electrolyte solution $\left(R_{s}\right)$, the charge transfer resistance $\left(\mathrm{R}_{\mathrm{ct}}\right)$; Warburg impedance $(\mathrm{W})$ and the capacity of the double layer (C). ${ }^{35}$ In the Nyquist plots, the diameter of the semicircle reflected the $R_{e t}$ value of redox conversion of the electroactive marker $\left[\mathrm{Fe}(\mathrm{CN})_{6}\right]^{3-14-}$ on the electrode at certain potential. From Figure 2, we can see the electrochemical response decreased at GNPs/GCE (Figure 2b, $135 \Omega$ ) compared to the bare GCE (Figure 2a, $350 \Omega$ ), which indicated a little bit fast electron transfer process of $\left[\mathrm{Fe}(\mathrm{CN})_{6}\right]^{3-14-}$ in GNPs/GCE, which also demonstrated that GNPs had been self-assembled on GCE. The self-assembly of PEG on GNPs/ GCE surface effectively blocked the $\left[\mathrm{Fe}(\mathrm{CN})_{6}\right]^{3-/ 4-}$ and thus led to an enhanced electron-transfer resistance (Figure 2c,

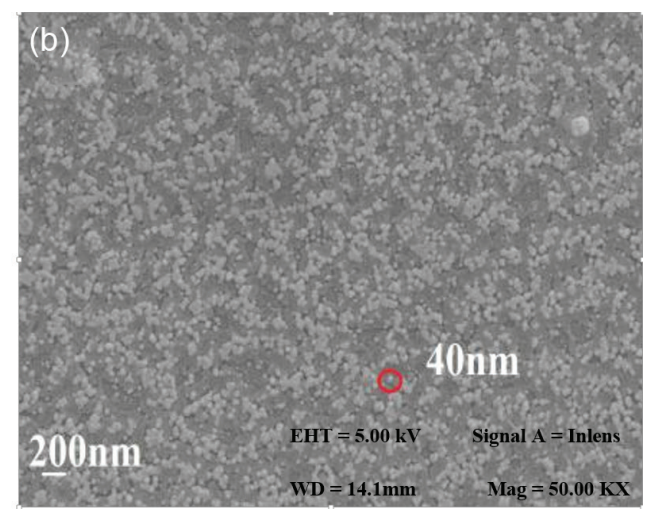

Figure 1. SEM images of bare GCE (a) and electrochemically deposited of GNPs on GCE (b). 
$3125.6 \Omega$ ). After peptide was immobilized onto PEG/GNPs/ GCE, the $R_{\text {et }}$ increased to $4465.7 \Omega$ (Figure $2 \mathrm{~d}$ ), which is probably attributed to the interaction of the peptide with GNPs to form Au-S bond. The electron-transfer resistance continued to increase after MCH droped (Figure 2e, $4770.6 \Omega$ ), this indicated that $\mathrm{MCH}$ was immobilized onto the surface of peptide/PEG/GNPs/GCE. Obviously, after further binding with $0.01 \mathrm{pg} \mathrm{mL}^{-1}$ LPS to the peptidebiosensor for 50 min, a much higher $\mathrm{R}_{\mathrm{et}}$ value was obtained (Figure 2f, $6221.7 \Omega$ ). This greatly increased $R_{e t}$ was attributed to the fact that peptide on GNPs can effectively capture LPS owing to the specific recognition ability of the peptide to LPS. This significant increase in the magnitude of $\mathrm{R}_{\mathrm{et}}$ indicated that the biosensor can respond to LPS.

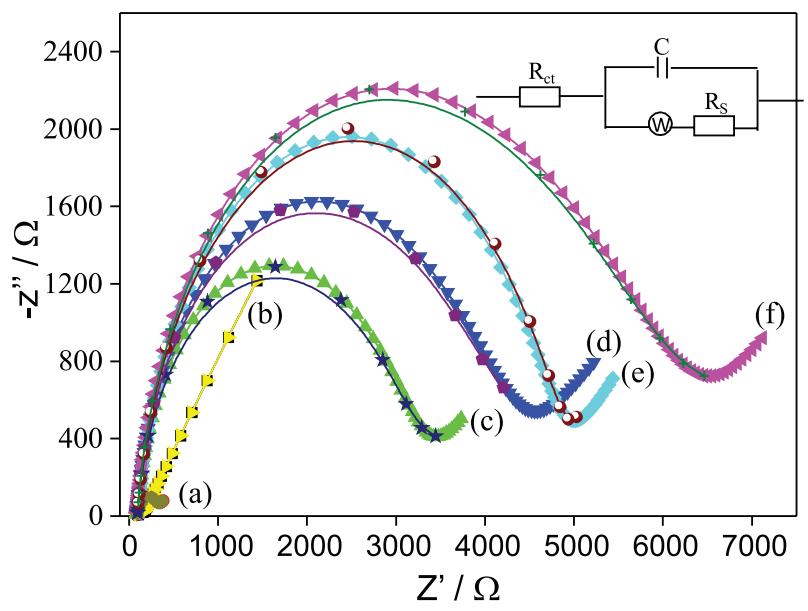

Figure 2. Nyquist plots of impedance spectra obtained in $5 \mathrm{mmol} \mathrm{L}^{-1}$ $\left[\mathrm{Fe}(\mathrm{CN})_{6}\right]^{3 / 4-}\left(0.10 \mathrm{~mol} \mathrm{~L}^{-1} \mathrm{PBS}, \mathrm{pH} 7.0\right)$. (a) Bare GCE; (b) GNPs/GCE; (c) PEG/GNPs/GCE; (d) peptide/PEG/GNPs/GCE; (e) MCH/peptide/ PEG/GNPs/GCE; and (f) LPS/MCH/peptide/PEG/GNPs/GCE. Inset: Randles equivalent circuit. LPS: $0.01 \mathrm{pg} \mathrm{mL}^{-1}$.

\section{Optimized conditions for the determination of LPS}

Generally, the amount and the self-assembly time of peptide affected the EIS response. The concentration of peptide was optimized in the range of 1.0-8.0 $\mu \mathrm{g} \mathrm{mL}^{-1}$. The result (as shown in Figure 3a) showed that the $\Delta R_{\mathrm{et}}$ increased markedly from 1 to $4 \mu \mathrm{g} \mathrm{mL} \mathrm{L}^{-1}$, which is attributed to the fact that a peptide layer was generated and the transfer of redox couple $\left[\mathrm{Fe}(\mathrm{CN})_{6}\right]^{3-14}$ was prohibited, which also indicated the amount of peptide on GNPs/GCE increased. When the concentration reached $4 \mu \mathrm{g} \mathrm{mL}^{-1}$, the $\Delta \mathrm{R}_{\mathrm{et}}$ was nearly the same as that in $8 \mu \mathrm{g} \mathrm{mL}^{-1}$, which suggested that the peptide almost occupied all reachable active sites of GNPs/GCE. Therefore, $4 \mu \mathrm{g} \mathrm{mL}^{-1}$ was selected in the following experiments to fabricate the peptide layer and to obtain a sensitive and stable signal.

The self-assembly time of peptide on the electrode was also investigated and the result were shown in Figure $3 \mathrm{~b}$.
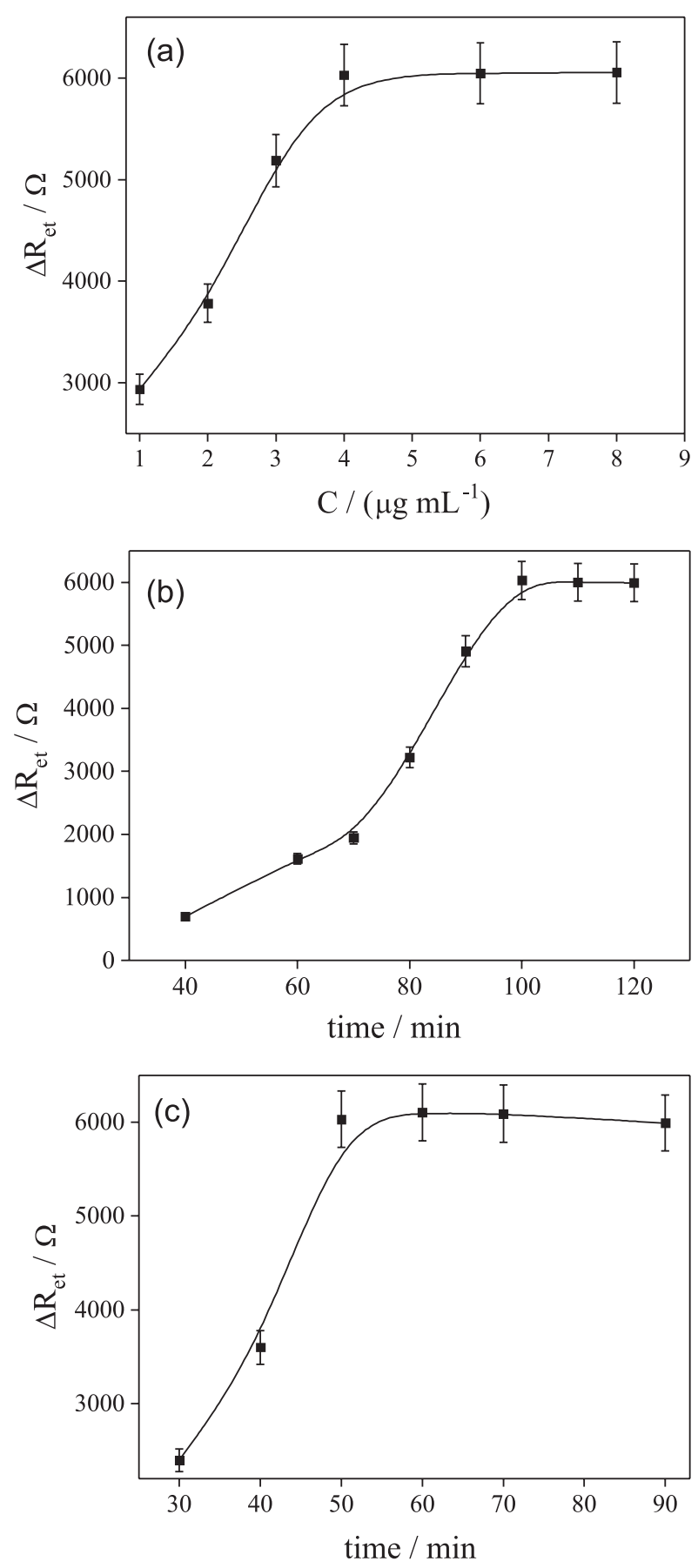

Figure 3. The effect of the concentration (a) and self-assembly time (b) of peptide; and interaction time of peptide and LPS (c) on the EIS response. LPS :1.0 pg mL ${ }^{-1}$; number of measurements: three.

As seen from Figure 3b, the EIS signals increased with the increase of the self-assembly time from 40 to $100 \mathrm{~min}$ and then almost did not increase from 100 to $120 \mathrm{~min}$. So, $100 \mathrm{~min}$ was chosen as the self-assembly time of peptide in the following experiments.

The EIS signals after interaction with $1.0 \mathrm{pg} \mathrm{mL}^{-1}$ LPS in different times was examined and the result was shown in Figure 3c. The results showed that the EIS 
signals increased with the increase of the interaction time from 30 to $50 \mathrm{~min}$ and then steady state was reached above $50 \mathrm{~min}$. This suggested that the initial reaction proceeded quickly and the reaction was completed in about $50 \mathrm{~min}$. Therefore, $50 \mathrm{~min}$ was chosen as the optimal interaction time between peptide and LPS in the following experiments.

\section{Performance of the biosensor for LPS}

The quantitative behavior of the biosensor was assessed by measuring the dependence of $\Delta \mathrm{R}_{\mathrm{et}}$ on the concentration of LPS. Figure 4A showed the Nyquist plots of the faradaic impedance spectra for the biosensor with different concentrations of LPS. Figure 4B showed the logarithmic relationship between $\Delta \mathrm{R}_{\mathrm{et}}$ and the concentration of LPS in the range of $0.01 \mathrm{pg} \mathrm{mL}^{-1}-1.0 \mathrm{ng} \mathrm{mL}^{-1}$. The regression equation was $\Delta \mathrm{R}_{\mathrm{et}}=2593.00 \log \mathrm{C}+6133.66(\mathrm{C}$ is in units of $\mathrm{pg} \mathrm{mL}^{-1}$ ) with a regression coefficient of 0.9879 . The limit of detection was $2.0 \mathrm{fg} \mathrm{mL}^{-1}$ (signal-to-noise ratio $(\mathrm{S} / \mathrm{N})=3, \mathrm{~S}=14690.56 \Omega, \mathrm{N}=4770.6 \Omega)$. For comparison

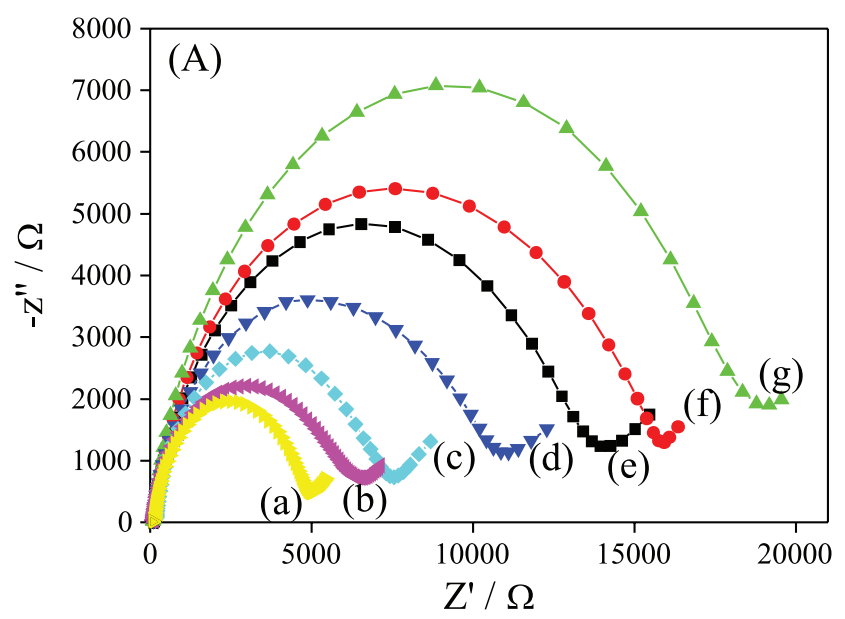

purposes, we summarized some biosensors previously reported for LPS in Table 1. As shown in Table 1, the limit of detection of the EIS biosensor in this work was lower than those of the previous methods for LPS detection, except Zhao et al.'s work. ${ }^{9}$ In addition, compared with previous reports, the sensitivity was very high.

The reproducibility of the biosensor was estimated for the detection of $1.0 \mathrm{pg} \mathrm{mL}^{-1}$ LPS. The relative standard deviation obtained was $3.9 \%$ using five individual biosensors and was $3.1 \%$ for seven independent measurements using the same biosensor. This indicated that the reproducibility of the fabricated biosensors was feasible. The storage ability of the EIS biosensor was also examined. After being stored at $4{ }^{\circ} \mathrm{C}$ in $0.1 \mathrm{~mol} \mathrm{~L}^{-1} \mathrm{PBS}$ (pH 7.0) for 1 week, the biosensor showed that the average EIS value was $97.8 \%$ of initial EIS value for $1.0 \mathrm{pg} \mathrm{mL}^{-1} \mathrm{LPS}$.

The possible interfering biomolecules were used to evaluate the selectivity of the sensor provided in this article following the steps described above. For the study with the interferents the ideal concentrations in the human serum must be used, e.g., $1.0 \mathrm{ng} \mathrm{mL}^{-1} \mathrm{BSA}, 1.0 \mathrm{ng} \mathrm{mL}^{-1} \mathrm{DNA}$,

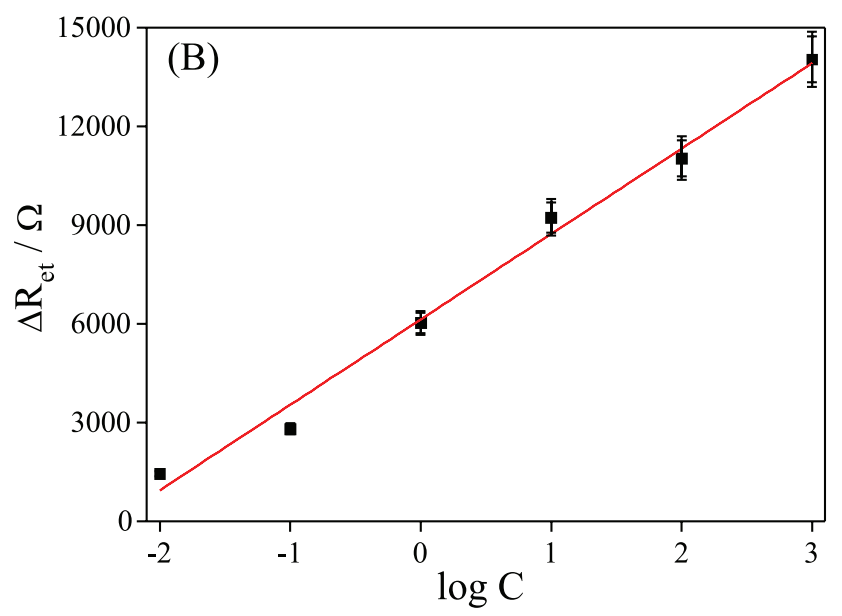

Figure 4. (A) Nyquist plots of impedance spectra of the EIS biosensor after interaction with different concentrations of LPS measured in $5 \mathrm{mmol} \mathrm{L}^{-1}$ $\left[\mathrm{Fe}(\mathrm{CN})_{6}\right]^{3-14}\left(0.10 \mathrm{~mol} \mathrm{~L}^{-1} \mathrm{PBS}, \mathrm{pH} 7.0\right)$ and (B) the standard curve of LPS. (a) 0 ; (b) $0.01 \mathrm{pg} \mathrm{mL}^{-1}$; (c) $0.1 \mathrm{pg} \mathrm{mL}^{-1}$; (d) $1.0 \mathrm{pg} \mathrm{mL}^{-1}$; (e) $10 \mathrm{pg} \mathrm{mL}^{-1}$; (f) $100 \mathrm{pg} \mathrm{mL}^{-1}$; and (g) $1.0 \mathrm{ng} \mathrm{mL} \mathrm{L}^{-1}$. Peptide: $4 \mathrm{\mu g} \mathrm{L}^{-1}$, self-assembly time of peptide: $100 \mathrm{~min}$; interaction time: 50 min; number of measurements: three.

Table 1. Detection for LPS using different sensors

\begin{tabular}{lcccc}
\hline Method & Range of linear concentration & Limit of detection & Sensitivity & Reference \\
\hline Fluorometric & $0-0.92 \mathrm{mg} \mathrm{mL}^{-1}$ & $2.20 \mu \mathrm{g} \mathrm{mL}-1$ & 8.54 a.u. $/ \log \left(\mu \mathrm{mol} \mathrm{L}^{-1}\right)$ & 5 \\
EC & $0.01 \mathrm{pg} \mathrm{mL}^{-1}-100 \mathrm{ng} \mathrm{mL}^{-1}$ & $3.3 \mathrm{fg} \mathrm{mL}$ & $2.63 \mu \mathrm{A} / \log \left(\mathrm{ng} \mathrm{mL}^{-1}\right)$ & 8 \\
ECL & $0.0001 \mathrm{pg} \mathrm{mL}^{-1}-50 \mathrm{ng} \mathrm{mL}^{-1}$ & $0.07 \mathrm{fg} \mathrm{mL}^{-1}$ & 1009.9 a.u. $/ \log \left(\mathrm{ng} \mathrm{mL}^{-1}\right)$ & 9 \\
EIS & $0.1 \mathrm{pg} \mathrm{mL}-1-0.1 \mathrm{ng} \mathrm{mL}^{-1}$ & $0.01 \mathrm{pg} \mathrm{mL}^{-1}$ & $35.1 \Omega / \log (\mathrm{ng} \mathrm{mL}-1)$ & 12 \\
EIS & $0.1 \mathrm{pg} \mathrm{mL}^{-1}-1 \mathrm{ng} \mathrm{mL}^{-1}$ & $0.03 \mathrm{pg} \mathrm{mL}^{-1}$ & $23237 \Omega / \log \left(\mathrm{ng} \mathrm{mL}^{-1}\right)$ & 13 \\
EIS & $1-50 \mathrm{mg} \mathrm{mL}^{-1}$ & $2.0 \mu \mathrm{gL}^{-1}$ & $11280 \Omega / \log \left(\mu \mathrm{mL}^{-1}\right)$ & 14 \\
This study & $0.01 \mathrm{pg} \mathrm{mL}^{-1}-1 \mathrm{ng} \mathrm{mL}^{-1}$ & $2.0 \mathrm{fg} \mathrm{mL}^{-1}$ & $2593 \Omega / \log \left(\mathrm{pg} \mathrm{mL}^{-1}\right)$ & -
\end{tabular}

EC: electrochemical; ECL: electrochemiluminescence; EIS: electrochemical impedance spectroscopy. 
Table 2. RSD and recovery results of the proposed biosensors in real serum samples $(n=3)$

\begin{tabular}{lcccc}
\hline Sample No. & Added concentration $/\left(\mathrm{pg} \mathrm{mL}^{-1}\right)$ & Found concentration / $\left.(\mathrm{pg} \mathrm{mL})^{-1}\right)$ & RSD / \% & Recovery / \% \\
\hline 1 & 1.00 & 1.15 & 2.29 & 115.0 \\
2 & 5.00 & 4.92 & 3.79 & 98.4 \\
3 & 10.00 & 10.15 & 3.19 & 101.5 \\
4 & 15.00 & 16.38 & 1.97 & 109.2 \\
5 & 20.00 & 19.65 & 2.89 & 98.2 \\
\hline
\end{tabular}

RSD: relative standard deviation.

$1.0 \mathrm{ng} \mathrm{mL}^{-1}$ ribonucleic acid (RNA), $1.0 \mathrm{ng} \mathrm{mL}^{-1} \mathrm{Glo}$, and $1.0 \mathrm{ng} \mathrm{mL}^{-1} \mathrm{Cho}$, and their EIS responses were recorded in Figure 5. Figure 5 showed that there were no obvious differences in the values of $\Delta \mathrm{R}_{\mathrm{et}}$ between BSA, DNA, RNA, glucose, and cholesterol; on the contrary, larger signal values were achieved in $1.0 \mathrm{ng} \mathrm{mL}^{-1}$ LPS. It was indicated that the $\mathrm{MCH} /$ peptide/PEG/GNPs/GCE showed a good selectivity for LPS over other biomolecule (the relative standard deviation between LPS and the other five substances was less than 5\%), which indicated the sensor provided had a good selectivity.

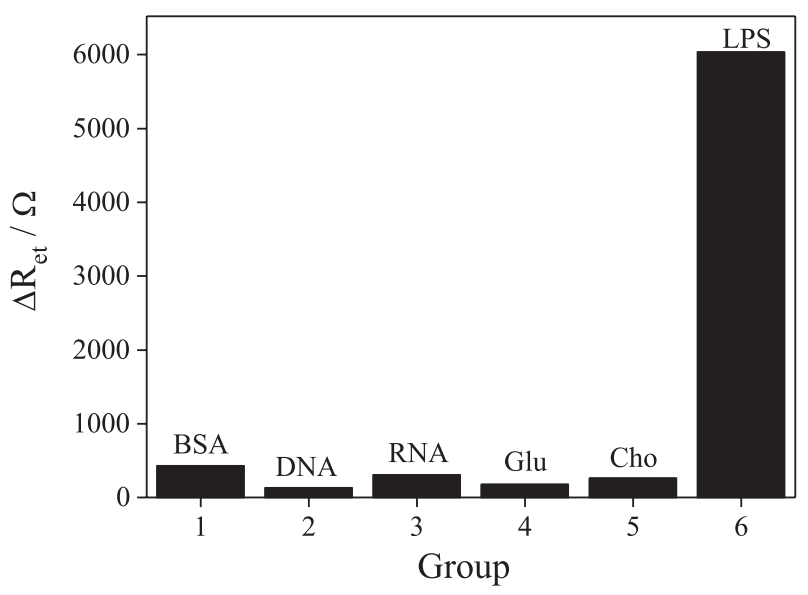

Figure 5. Selectivity of the peptide biosensor to some biological species: $1.0 \mathrm{ng} \mathrm{mL}^{-1} \mathrm{BSA}, 1.0 \mathrm{ng} \mathrm{mL}^{-1} \mathrm{DNA}, 1.0 \mathrm{ng} \mathrm{mL}^{-1} \mathrm{RNA}, 1.0 \mathrm{ng} \mathrm{mL}^{-1}$ glucose (Glu), $1.0 \mathrm{ng} \mathrm{mL}^{-1}$ cholesterol (Cho), and $1.0 \mathrm{pg} \mathrm{mL}^{-1}$ LPS. No. of measurements: three.

The real sample assay of the proposed biosensors

In order to evaluate the practical application of the biosensors, a real sample was estimated by spiking different concentrations of LPS into 50-fold-diluted serum samples (obtained from Shangluo Hospital, China). The experimental results were shown in Table 2. The relative standard deviation (RSD) of each sample for five parallel detections was less than $3.79 \%$ and the recovery varied from $98.4-115.0 \%$.

\section{Conclusions}

A simple and sensitive label free EIS biosensor based on a specific peptide as molecular recognition molecule has been developed for the determination of LPS. The biosensor has high sensitivity, reproducibility and selectivity for using GNPs, which can effectively fix the peptide and enhance the increased EIS response. The strategy presented in this paper could be extended to develop other biosensing methods for other biological molecules.

\section{Acknowledgments}

This work was financially supported by the National Natural Science Foundation of China (No. 30970696), the Science and Technology Planning Project (2012KTDZ 02-02), the Natural Science Basic Research Plan in Shaanxi Province of China (2018JM2040), Open Fund Project of Shaanxi Key Laboratory for comprehensive utilization of tailings resources (2017SKY-WK007), and the Science and Technology Innovation Team Project of Shangluo University (18SCX005).

\section{References}

1. Yang, J.; Huang, L.; Guo, Z. Y.; Ren, W.; Wang, Q. S.; J. Lumin. 2016, 172, 290.

2. Ding, S. J.; Chang, B. W.; Wu, C. C.; Chen, C. J.; Chang, H. C.; Electrochem. Commun. 2007, 9, 1206.

3. Zhang, G.; Baek, L.; Nielsen, P. E.; Buchardt, O.; Koch, C.; J. Clin. Microbiol. 1994, 32, 416.

4. Rangin, M.; Basu, A.; J. Am. Chem. Soc. 2004, 126, 5038.

5. Lim, S. K.; Chen, P.; Lee, F. L.; Moochhala, S.; Liedberg, B.; Anal. Chem. 2015, 87, 9408.

6. Zeng, L. T.; Wu, J. S.; Dai, Q.; Liu, W.; Wang, P. F.; Lee, C. S.; Org. Lett. 2010, 12, 4014.

7. Bai, L. J.; Chai, Y. Q.; Pu, X. Y.; Yuan, R.; Nanoscale 2014, 6, 2902.

8. Shen, W. J.; Zhuo, Y.; Chai, Y. Q.; Yuan, R.; Biosens. Bioelectron. 2016, 83, 287. 
9. Zhao, M.; Chen, A.; Huang, D.; Chai, Y. Q.; Zhuo, Y.; Yuan, R.; Anal. Chem. 2017, 89, 8335.

10. Seriburi, P.; McGuire, S.; Shastry, A.; Bringer, K. F.; Meldrum, D. R.; Anal. Chem. 2008, 80, 3677.

11. Chen, H.; Heng, C. K.; Puiu, P. D.; Zhou, X. D.; Lee, A. C.; Lim, T. M.; Tan, S. N.; Anal. Chim. Acta 2005, 554, 52.

12. Cho, M.; Chun, L. M.; Lin, M.; Choe, W.; Nam, J.; Lee, Y. K.; Sens. Actuators, B 2012, 174, 490.

13. Su, W. Q.; Cho, M. S.; Nam, J.; Choe, W.; Lee, Y.; Electroanalysis 2013, 25, 380.

14. Brosel-Oliu, S.; Galyamin, D.; Abramova, N.; Muñoz-Pascual, F.-X.; Bratov, A.; Electrochim. Acta 2017, 243, 142.

15. Qi, H. L.; Li, M.; Dong, M.; Ruan, S. P.; Gao, Q.; Zhang, C. X.; Anal. Chem. 2014, 86, 1372.

16. Moss, M. L.; Koller, G.; Bartsch, J. W.; Rakow, S.; Schlomann, U.; Rasmussen, F. H.; Anal. Biochem. 2015, 484, 75.

17. Suaifan, G.; Alhogail, S.; Zourob, M.; Biosens. Bioelectron. 2017, 92, 702 .

18. Teengam, P.; Siangproh, W.; Tuantranont, A.; Vilaivan, T.; Chailapakul, O.; Henry, C. S.; Anal. Chem. 2017, 89, 5428.

19. Wang, Z.; Li, X.; Feng, D.; Li, L.; Shi, W.; Ma, H.; Anal. Chem. 2014, 86, 7719.

20. Choi, J. H.; Kim, H. S.; Choi, J. W.; Hong, J. W.; Kim, Y. K.; Oh, B. K.; Biosens. Bioelectron. 2013, 49, 415.

21. Suzuki, Y.; Sens. Actuators, B 2018, 276, 230.

22. Nian, L. G.; Hu, Y.; Fu, C. H.; Song, C.; Wang, J.; Xiao, J. X.; Talanta 2018, 176, 492.

23. Jing, P.; Yi, H.; Xue, S.; Yuan, R.; Xu, W.; RSC Adv. 2015, 5 , 65725 .
24. Lin, Y. Y.; Shen, R. K.; Liu, N. N.; Yi, H.; Dai, H.; Lin, J. H.; Anal. Chim. Acta 2018, 1035, 175.

25. Meng, F. Y.; Liang, W. G.; Sun, H. X.; Wu, L. G.; Gong, X.; Miao, P.; ChemElectroChem 2017, 4, 472.

26. Horsley, J. R.; Yu, J. X.; Wegener, K. L.; Hoppmann, C.; RuckBraun, K.; Abell, A. D.; Biosens. Bioelectron. 2018, 118, 188.

27. Dang, Q.; Gao, H. F.; Li, Z. J.; Qi, H. L.; Gao, Q.; Zhang, C. X.; Anal. Bioanal. Chem. 2016, 408, 7067.

28. Wu, F. F.; Zhou, Y.; Zhang, H.; Yuan, R.; Chai, Y. Q.; Anal. Chem. 2018, 90, 2263.

29. Yang, X. L.; Zhao, Y.; Sun, L. J.; Qi, H. L.; Gao, Q.; Zhang, C. X.; Sens. Actuators, B 2018, 257, 60.

30. Huang, C. X.; Chen, X.; Lu, Y. L.; Yang, H.; Yang, W. S.; Biosens. Bioelectron. 2015, 63, 478.

31. Lei, C. Y.; Qiao, Z. H.; Fu, Y. C.; Li, Y. B.; Anal. Methods 2016, 8,8079 .

32. Li, X.; Shen, L.; Zhang, D.; Qi, H.; Cao, Q.; Ma, F.; Zhang, C.; Biosens. Bioelectron. 2008, 23, 1624.

33. Qi, H. L.; Wang, C.; Cheng, N.; Microchim. Acta 2010, 170, 33.

34. Wang, B.; Jing, R.; Qi, H. L.; Gao, Q.; Zhang, C. X.; J. Electroanal. Chem. 2016, 781, 212.

35. Zhao, L.; Li, X.; Lin, Y.; Yang, L.; Yu, P.; Mao, L.; Analyst 2012, 137, 2199.

Submitted: December 20, 2018

Published online: May 7, 2019 